\title{
Pendampingan Peningkatan Profesionalitas Guru Bahasa Indonesia Melalui Literasi Menulis Artikel di Jurnal Ilmiah
}

\author{
Muhlis Fajar Wicaksana*1, Suparmin $^{2}$, Titik Sudiatmi ${ }^{3}$, Sri Muryati ${ }^{4}$ \\ muhlisfajarwicaksana@gmail.com*1; sparmin@ gmail.com²; titiksudiatmi2@gmail.com³ \\ srimuryati411@gmail.com ${ }^{4}$ \\ 1,2,3,4 Fakultas Keguruan dan Ilmu Pendidikan (FKIP) \\ Universitas Veteran Bangun Nusantara Sukoharjo
}

Received: 8 Juli 2021

Accepted: 12 Juli $2021 \quad$ Online Published: 31 Juli 2021

DOI: 10.29408/ab.v2i1.3776

URL: http://dx.doi.org/10.29408/ab.v2i1.3776

\begin{abstract}
Abstrak: Guru-guru saat ini dituntut untuk menghasilkan karya ilmiah, khusunya menulis artikel ilmiah. Tujuan pengabdian masyarakat ini untuk meningkatkan literasi profesionalitas guru dalam menulis artikel ilmiah. Adapun metode yang diterapkan dalam kegiatan pengabdian kepada masyarakat melalui deskriptif kualitatif. Melalui kegiatan pelatihan dan pendampingan yang diperuntukkan bagi guru-guru musyawarah guru mata pelajaran (MGMP) SMA Bahasa Indonesia di Sukoharjo. Metode pelaksanaan dalam pengabdian masyarakat dilakukan melalui tahapan berikut: 1) persiapan (observasi dan rencana aksi); 2) implementasi; 3) evaluasi dan umpan balik; 4) pendampingan menyusun artikel ilmiah. Adapun hasil dari pelatihan ini meliputi; adanya respons positif dari peserta pelatihan dan meningkatnya keterampilan guru dalam berliterasi menulis artikel ilmiah. Hasil akhir menunjukkan dari 30 peserta yang mengikuti pendampingan, terdapat 10 naskah artikel ilmiah guru Bahasa Indonesia di Sukoharjo yang sudah disesuaikan dengan template jurnal ilmiah yang akan dituju. Jurnal-jurnal yang akan dituju antara lain, Jurnal Klitika; Jurnal Ilmiah Pendidikan Bahasa Dan Sastra Indonesia Univet Bantara; Jurnal Basastra; Jurnal Pendidikan Bahasa dan Pengajarannya Universitas Sebelas Maret; Jurnal TABASA; Jurnal Ilmiah Tadris Bahasa Indonesia IAIN Surakarta; dan Jurnal Linguista; Universitas PGRI Madiun. Jika dipersentasekan sejumlah 33\% peserta berhasil submit dalam mencapai tujuan untuk publish di jurnal ilmiah yang diinginkan, sebanyak $45 \%$ berhasil mengubah laporan PTK kedalam artikel, sisanya sejumlah 22\% masih berkutat pada revisi dalam proses mengubah laporan menjadi artikel. Dapat disimpulkan bahwa, secara total, sebesar $78 \%$ dari jumlah keseluruhan sudah menunjukkan progres yang maksimal dalam proses pendampingan.
\end{abstract}

Kata Kunci: Bahasa Indonesia; Jurnal Ilmiah; Literasi; Pelatihan Menulis;

\begin{abstract}
Teachers are currently required to produce scientific works, especially writing scientific articles. The purpose of this community service is to improve teacher professionalism literacy in writing scientific articles. The method applied in community service activities is descriptive qualitative through training and mentoring activities intended for teachers of the Indonesian Language Senior High School Subject Teacher Consultation (MGMP) in Sukoharjo. The implementation method in community service is carried out through the following stages: 1) preparation (observations and action plans); 2) implementation; 3) evaluation and feedback; 4) assistance in compiling scientific articles. The results of this training include a positive response from the trainees and an increase in the skills of teachers in literacy in writing scientific articles. The final results showed that of the 30 participants who participated in the mentoring, there were ten manuscripts of scientific articles for Indonesian language teachers in Sukoharjo adapted to the scientific journal templates to be addressed. The journals targeted include Klitika Journal; Scientific Journal of Indonesian Language and Literature Education, Univet Bantara; Literature Journal; Journal of Language Education and Teaching Sebelas Maret University; TABASA Journal; Indonesian Language Tadris Scientific Journal IAIN Surakarta; and the Linguistic Journal; PGRI Madiun University. If a percentage of 33\% of participants succeeded in submitting in achieving the goal of publishing in
\end{abstract}


Wicaksana, M. F., Suparmin, S., Sudiatmi, T., Muryati, S. (2021). Pendampingan peningkatan profesionalitas guru Bahasa Indonesia melalui literasi menulis artikel di jurnal ilmiah. ABSYARA: Jurnal Pengabdian Pada Masyarakat, 2(1), 128-136. doi:10.29408/ab.v2i1.3776

the desired scientific journal, as many as $45 \%$ succeeded in converting the PTK report into articles, the remaining $22 \%$ were still struggling with revisions of converting reports into articles. It can be concluded that, in total, $78 \%$ of the total number has shown maximum progress in the mentoring process.

Keyword: Indonesia Language; Literacy; Scientific Journals; Writing Training;

\section{PENDAHULUAN}

Pemerintah membuat beberapa peraturan seperti pada UU No 14 Tahun 2005 tentang guru dan dosen, dalam bab III tentang prinsip Salah satu keterampilan menulis yang harus dikuasai oleh guru dan harus dilakukan adalah keterampilan menulis karya ilmiah. Peraturan Menteri Negara Pendayagunaan Aparatur Negara dan Reformasi Birokrasi Nomor PER/16/M.PAN-RB/11/2009 tentang Jabatan Fungsional Guru dan Angka Kreditnya, memberikan dampak yang luar biasa bagi kemampuan menulis guru. Berdasarkan hasil laporan karya ilmiah ini, guru juga harus mempublikasikannya sebagai artikel hasil penelitian. profesionalitas, disebutkan bahwa guru selain dituntut memiliki kualifikasi akademik, latar belakang pendidikan, serta kompetensi yang diperlukan sesuai dengan bidang tugasnya, juga dituntut untuk mengembangkan keprofesionalannya secara berkelanjutan dengan belajar sepanjang hayat.

Aturan kewajiban menulis publikasi ilmiah telah diberlakukan mulai tahun 2011 bagi guru yang hendak naik dari golongan IV/a ke IV/b (Noorjannah, 2014; Ilfiandra dkk., 2016). Aturan ini menyebabkan guru pegawai negeri sipil bertumpuk di golongan IV/a karena banyak di antara mereka yang tidak memenuhi kewajiban membuat karya ilmiah. Kini pemerintah mengeluarkan aturan baru yang mengharuskan guru untuk membuat publikasi ilmiah atau karya inovatif jika akan naik dari golongan III/b ke III/c. Semakin tinggi golongan, kewajiban membuat publikasi ilmiah semakin bertambah.

Berdasarkan kajian empiris dilapangan, dari guru-guru Bahasa Indonesia sekolah menengah atas yang ada di Sukoharjo, baru $0,5 \%$ saja yang telah berhasil melaksanakannya. Sayangnya banyak guru yang belum memiliki kemampuan atau bahkan belum menulis karya ilmiah yang dipublikasikan (Wahyuningtyas \& Ratnawati, 2018; Priyanto \& Rohartati, 2019); (Firdaus, dkk, 2020). Banyak guru yang menyerah pada keadaan, ini, hingga menunggu masa pensiunnya. Guru beralasan bahwa sangat sulit dalam mewujudkan kegiatan menulis tersebut. Selain kegiatannya yang dirasakan rumit, guru harus susah payah menunggu lamanya artikel yang dimasukkan pada jurnal tertentu karena tahapan seleksi terbit yang lama. Hal inilah yang menjadi sebagian guru menyerah dengan keadaan.

Selain itu, secara umum di Indonesia kemampuan menulis artikel ilmiah para guru cukup memprihatinkan. Hal ini sejalan dengan Isa, dkk. (2016); Hutajulu, dkk. (2020) menyatakan bahwa kemampuan menulis artikel ilmiah di Indonesia sangat rendah dibanding dengan negara-negara tetangga. Sehingga para pendidik perlu mengikuti sosialisasi ataupun pelatihan sehingga para pendidik, baik guru maupun dosen memiliki keahlian yang berperan penting dalam pendidikan khususnya terhadap peningkatan kualitas Pendidikan.

Salah satu bentuk alternatif solusi mengatasi rendahnya guru dalam publikasi artikel ilmiah, peneliti mencoba untuk mendampingi guru-guru sekolah menengah atas (SMA) untuk mnulis artikel ilmiah. Kegiatan diawali dari mengubah laporan hasil penelitian Tindakan kelas 
dilanjutkan dengan memotong-motong bagian laporan untuk menjadi bagian isi dari artikel ilmiah. Pendampingan dilakukan dalam 3 hari secara intensif pembimbingan satu-persatu. Hari terakhir, draf artikel ilmiah yang sudah tersusun oleh guru, dibantu untuk submit di jurnal ilmiah yang dituju.

\section{METODE PELAKSANAAN}

\section{Waktu dan Lokasi}

Kegiatan pengabdian kepada masyarakat ini dilakukan pada tanggal 27-28 Mei 2021. Kegiatan ini dilakukan secara luring dan daring dengan menggunakan zoom. Dengan jumlah peserta 30 orang guru.

\section{Prosedur pelaksanaan}

Metode pelaksanaan kegiatan pengabdian kepada Masayarakat ini dilakukan melalui pendekatan deskriptif kualitatif. Kegiatan dilakukan melalui pelatihan dan pendampingan guru-guru yang tergabung di MGMP Bahasa Indonesia SMA. Keggiatan ini memuat hal-hal berikut ini, yang meliputi: (1) pelatihan mengubah hasil laporan penelitian kedalam artikel; mulai dari bab 1-5; (2) pendampingan penyusunan artikel hasil mengubah bab 1-5; (3) review hasil penyusunan pendampingan hasil mengubah bab 1-5 ke dalam artikel; (4) mengirim hasil review artikel ke jurnal artikel yang akan dituju. Adapun prosedur pelaksanaanya dapat digambarkan sebagai berikut:

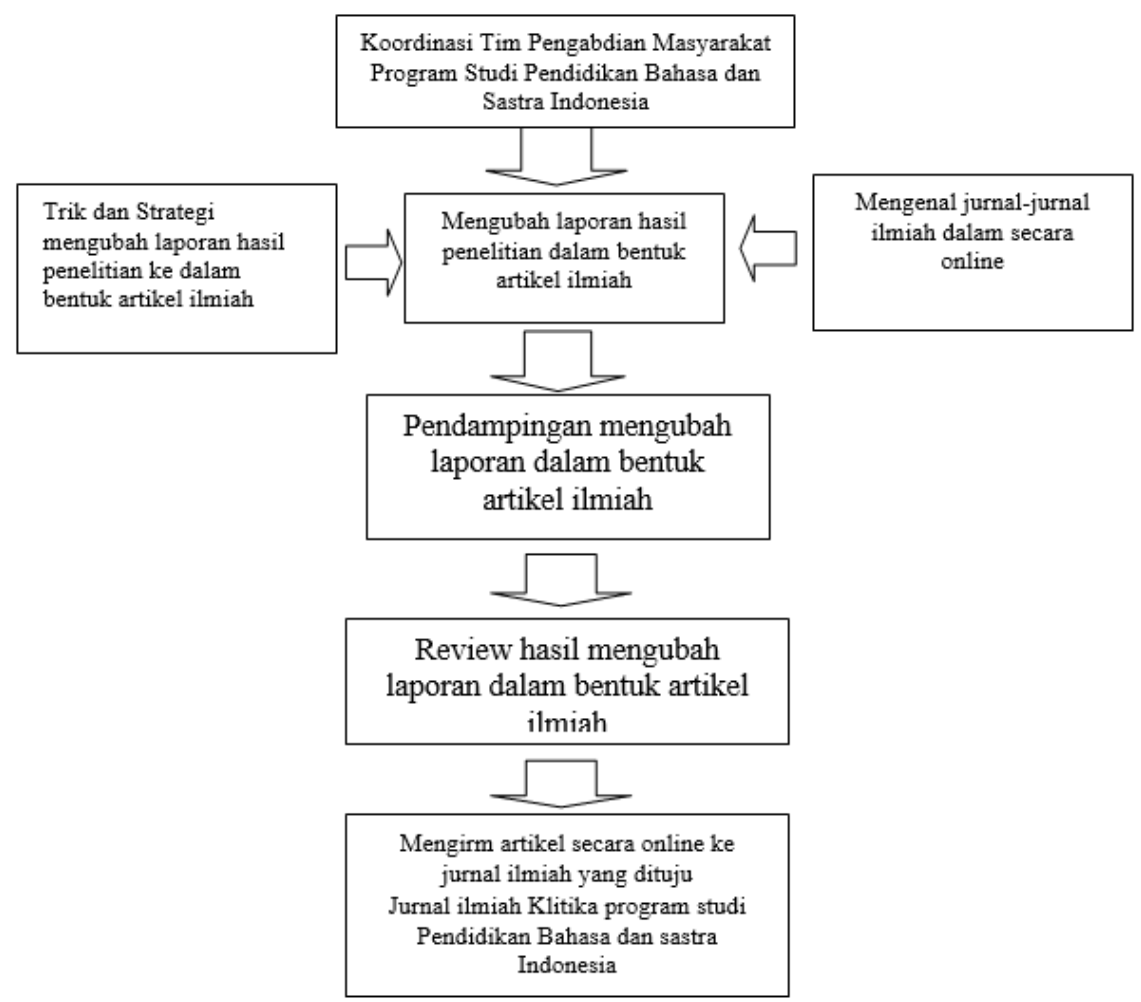

Gambar 1. Metode Pelaksanaan Pengabdian Masyarakat 


\section{HASIL DAN PEMBAHASAN HASIL}

Hasil pelaksanaan pengabdian kepada masyarakat ini terbagi dalam berbagai cakupan. Adapun cakupannya meliputi: 1) memberikan wawasan kepada guru tentang kebijakan kementrian Pendidikan dan kebudayaan republik Indonesia terkait menulis artikel ilmiah;2) memberikan trik dan strategi mengubah laporan hasil penelitian menjadi artikel ilmiah; 3) Mengenal sistematika penulisan Artikel Jurnal Ilmiah; 4) praktik pendampingan guru dalam menyusunan artikel ilmiah sesuai jurnal yang dituju; 5) submit artikel ilmiah yang sudah tersusun ke alamat jurnal ilmiah yang dituju. Berdasarkan permasalahan yang dihadapi oleh guru bahasa Indonesia di Sukoharjo, mereka sulit untuk menaikkan angka kredit kepangkatan (PAK) disebabkan oleh karya ilmiah, baik itu dalam melaksanakan penelitian dilanjutkan menyususn laporannya, ataupun mengubah laporan menjadi artikel untuk dipublikasikan dalam jurnal ilmiah. Hal inilah yang membuat penulis ingin membantu dan berbagi ilmu pengetahuan dan pengalaman melalui kegiatan pengabdian kepada masyarakat ini.

Berdasarkan hasil evaluasi Keberhasilan dan pelaksanaan program pengabdian kepada masyarakat ini dibatasi pada cakupan yang keempat, yaitu praktik pendampingan guru dalam menyusunan artikel ilmiah sesuai jurnal yang dituju, dapat dilihat dari dua tolok ukur sebagai beriku: 1) Respons positif dari peserta pelatihan menulis artikel ilmiah; dan 2) meningkatnya keterampilan menulis artikel ilmiah guru Bahasa Indonesia setelah mendapatkan pelatihan. Adapun gambaran uraian kegiatannya sebagai berikut:

\section{Respons Positif dari Peserta Pelatihan}

Respons peserta pelatihan akan diukur melalui observasi selama pelatihan berlangsung dan dengan memberikan angket kuesioner yang menyangkut kesan, saran, kritik dan usulan peserta pelatihan terhadap program pengabdian kepada masyarakat ini. berdasarkan pelaksanaan kegiatan pelatihan, para guru MGMP bahasa Indonesia SMA di Kabupaten Sukoharjo terlihat sangat antusias mengikuti. Begitu pemateri menyampaikan materi, para guru dengan suasana kondusif memperhatikan dengan sungguh-sungguh. Dalam kegiatan pendampingan ini dilakukan melalui luring atau tatap muka dan daring (virtual). Kegiatan luring atau tatap muka dilakukan satu kali pada tanggal 27 Mei 2021. Adapun dokumentasi kegiatan dapat dilihat pada gambar 2 berikut.

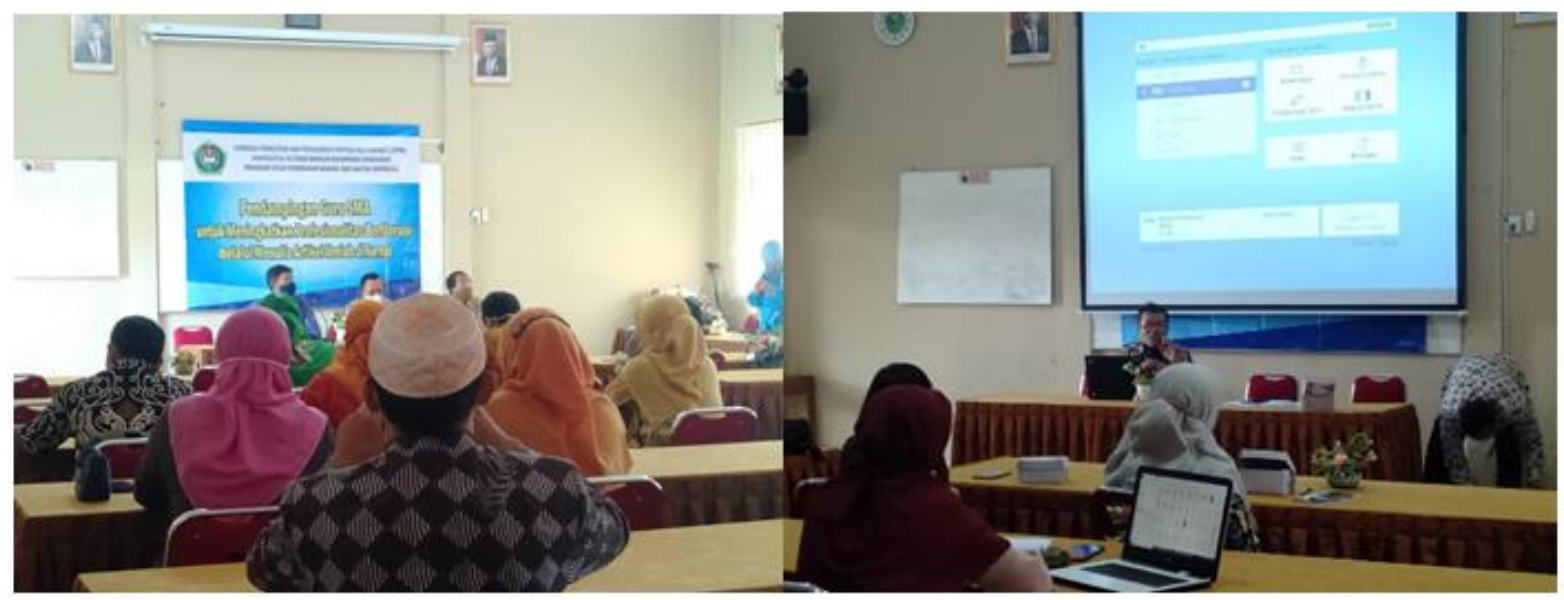

Gambar 2. Kegiatan Pendampingan Guru secara Luring atau Tatap Muka 
Berdasarkan gambar 1 dari kegiatan pendampingan guru secara luring atau tatap muka terlihat guru sangat antusias untuk mengikutinya. Terlihat salah satu guru mempraktikkan apa yang disampaikan oleh pemateri melalui notebook. Dalam kegiatan tersebut guru mulai mengubah laporan hasil penelitiannya menjadi artikel ilmiah. Diawali dari penyusunan abstrak hasil penelitian yang ingin dipaparkan. Laporan penelitian guru ini dapat dijadikan beberapa artikel ilmiah sesuai jurnal yang dituju. Pemateri memberikan saran satu laporan hasil penelitian alangkah baiknya dijadikan artikel ilmiah lebih dari satu.

Selain melalui kegiatan luring atau tatap muka di sekolah, kegiatan pendampingan dilakukan secara daring. Melihat situasi dan kondisi masih masa pembatasan ruang gerak berskala kecil/mikro. Tidak kalah dengan kegiatan luring atau tatap muka, kegiatan melalui daring juga mendapatkan apresiasi sangat tinggi oleh guru-guru Bahasa Indonesia. Terdapat 30 peserta yang mengikuti pendampingan dalam menyusun artikel ilmiah. Setelah dalam kegiatan luring atau tatap muka menyusun abstrak artikel, selanjutnya dalam kegiatan daring pendampingan pada kegiatan menyusun bagian pendahuluan, landasan teorinya, dan metode penelitian.

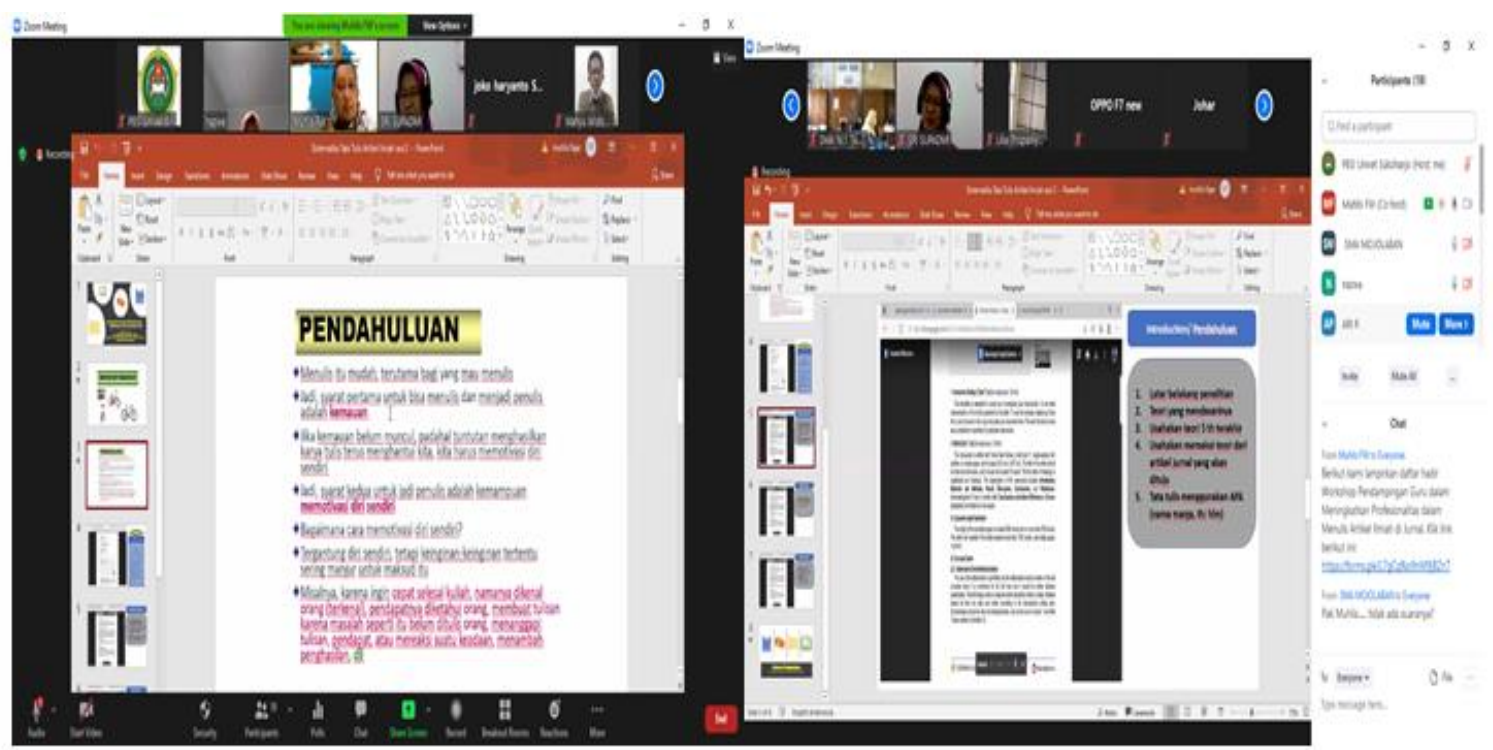

Gambar 3. Kegiatan Pendampingan Guru secara Daring

Kegiatan pendampingan hari terakhir dalam praktik menyusun artikel ilmiah yaitu melanjutkan dengan kegiatan penyusunan hasil penelitian dan pembahasan, penyusunan simpulan dan saran, kemudian terakhir penyusunan daftar Pustaka. Kegiatan ini dilaksanakan melalui daring. Terlihat guru-guru sangat antusias dalam mengikutinya. Guruguru dengan kesadarannya mengikuti terus agar pengetahuan dan pengalaman dalam menulis artikel ilmiah tidak terputus di tengah jalan. Atau dengan kata lain, ilmu yang didapatkan secara lengkap. Kegiatan ini dapat dilihat pada gambar 3 berikut ini. 

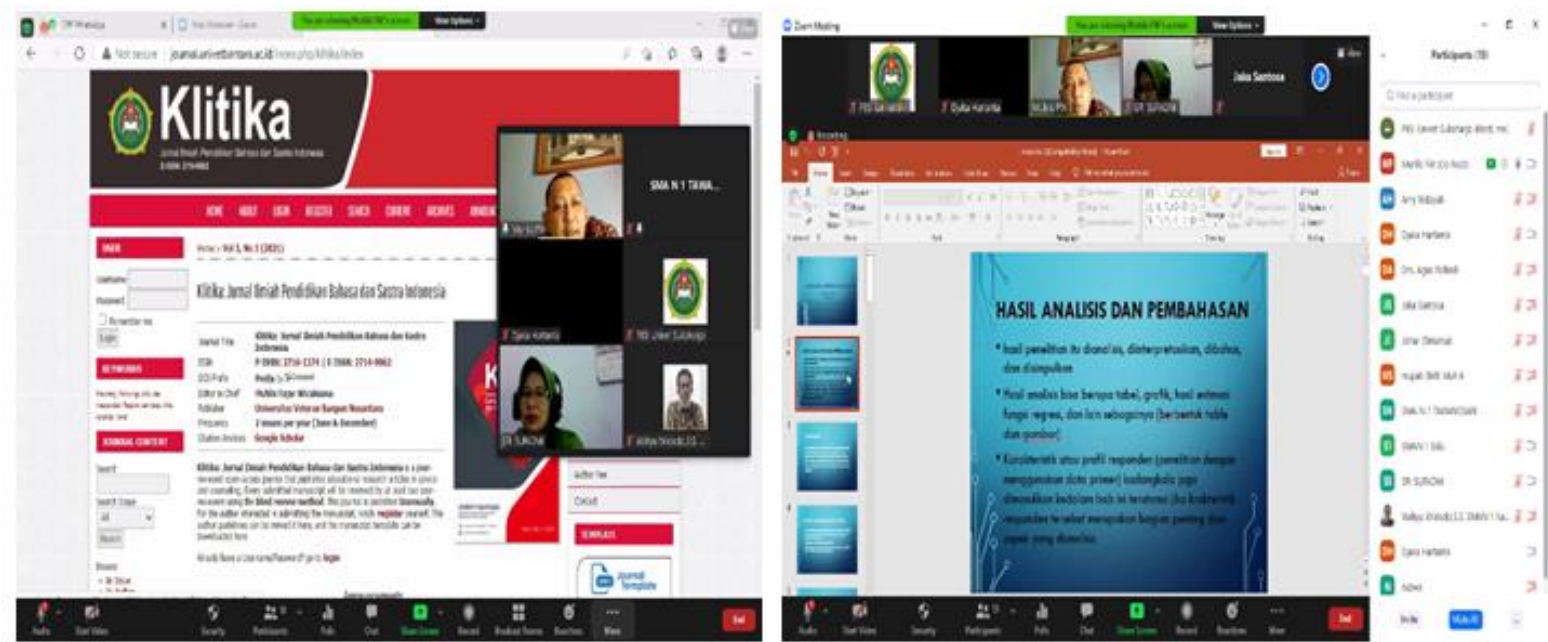

Gambar 4. Kegiatan Pendampingan Guru secara Daring

Setelah guru mengikuti pendampingan dalam mengubah laporan hasil penelitian menjadi artikel ilmiah, guru merasa tidak sulit dalam merealisasikannya. Guru merasa mendapatkan informasi terbaru dari kegiatan ini. Guru merasa termotivasi untuk menulis kembali setelah beberapa waktu tidak ingin menulis dengan berbagai kesibukannya di sekolah. Guru berjanji akan mewujudkannya minimal satu artikel dari kegiatan ini.

\section{Keterampilan Guru dalam Berliterasi Menulis Artikel Ilmiah}

Setelah mendapatkan pendampingan dalam mengubah hasil laporan penelitian menjadi artikel ilmiah, kemampuan guru dalam mempersiapkan artikel ilmiah cukup menunjukkan progress yang baik. Indikator ini ditandai dari 30 peserta yang mengikuti pendampingan, terdapat sebesar $33 \%$ peserta berhasil submit dalam mencapai tujuan untuk publish di jurnal ilmiah yang diinginkan. Adapun sebanyak $45 \%$ berhasil mengubah laporan PTK kedalam artikel. Dalam tahapan ini guru sudah dapat mengubah laporan kedalam bentuk artikel ilmiah. Sisanya sejumlah $22 \%$ masih berkutat pada revisi dalam proses mengubah laporan penelitian tindakan kelas (PTK) menjadi artikel. Jika dihitung secara total, sebesar 78\% dari jumlah keseluruhan sudah menunjukkan progres yang maksimal dalam proses pendampingan.

Peserta pendampingan menulis artikel ilmiah di jurnal sebesar 33\% sudah submit di jurnal ilmiah yang diinginkan. Jurnal-jurnal yang dituju antara lain, Jurnal Klitika; Jurnal Ilmiah Pendidikan Bahasa Dan Sastra Indonesia Univet Bantara; Jurnal Basastra; Jurnal Pendidikan Bahasa dan Pengajarannya Universitas Sebelas Maret; Jurnal TABASA; Jurnal Ilmiah Tadris Bahasa Indonesia IAIN Surakarta; dan Jurnal Linguista; Universitas PGRI Madiun. Setelah pendampingan ini guru merasa mempunyai rasa kepercayaan diri yang tinggi setelah mengikuti program pendampingan ini. Guru merasa tidak ada permasalahan lagi ketika akan menyususun artikel ilmiah. Guru siap menulis, menulis, dan menulis. 


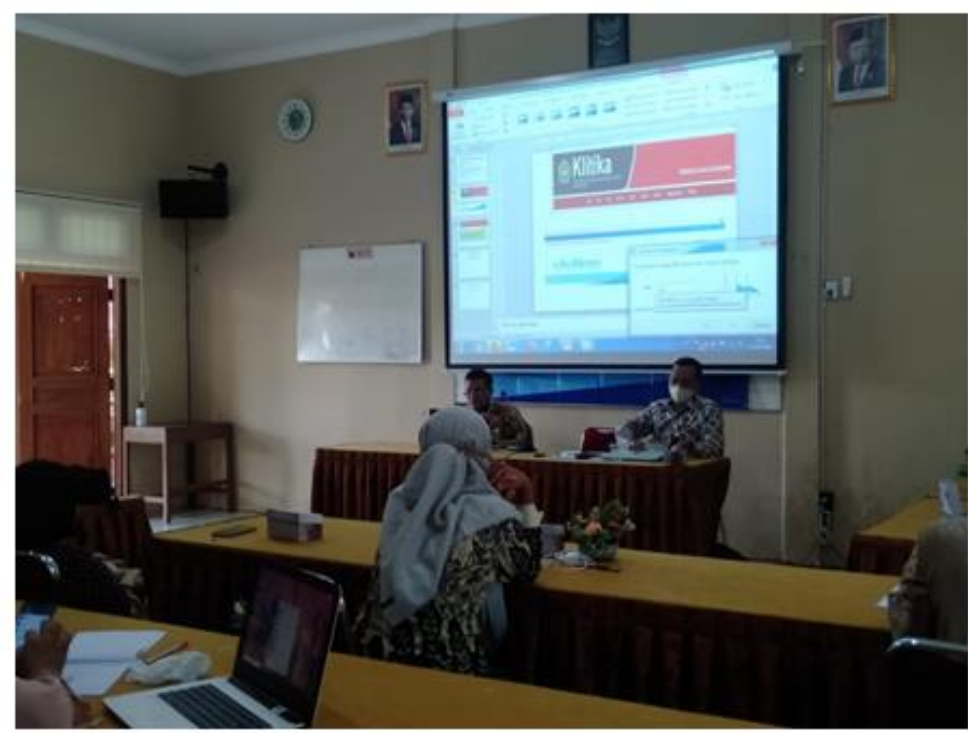

\section{Gambar 4. Kegiatan Pendampingan Guru Submit ke Alamat Jurnal Klitika}

Terlihat dari gambar kegiatan gambar 4 merupakan kegiatan secara luring Bersama-sama mensubmit artikel yang telah jadi untuk submit ke alamat yang jurnal yang dituju. Jurnal yang dituju pada waktu itu adalah di jurnal Klitika Universitas Veteran Bangun Nusantara, jurnal Basastra Universitas Sebelas Maret, jurnal Linguista Universitas PGRI Madiun Jawa Timur. Pertimbangan mengirimkan ke alamat-alamat jurnal tersebut karena respon yang sangat cepat adanya artikel yang masuk ke sistem pengelola jurnal.

\section{PEMBAHASAN}

Keterampilan dan kemampuan guru dalam menulis karya Ilmiah di Sukoharjo perlu untuk dioptimalkan. Prestasi guru dalam menulis karya ilmiah perlu ditingkatkan. Berbagai sebab diutarakan oleh guru mengapa keterampilan dan kemampuan menulisnya kurang berkembang. Kurangnya penguasaan metode ilmiah dan keterbatasan pada pengaksesan informasi pada guru mengakibatkan lemahnya kemampuan guru dalam menghasilkan karya tulis ilmiah (Kompas, 2010). Oleh sebab itu, penting bagi guru untuk menambah wawasan dan keterampilan dalam bidang-bidang tersebut. Hasil kegiatan pengabdian masyarakat bagi guruguru SD Inpres 111 Sero dalam bidang penulisan artikel ilmiah ini sangat mendukung pengembangan kemampuan guru dalam menuju profesionalitasnya (Aisyah \& Mahanani, 2017). Terdapat beberapa alasan para guru ini tidak memperhatikan masalah menulis artikel ilmiah ini. Mulai disebabkan oleh tidak adanya waktu untuk menulis, penelitian, membaca, apalagi publikasi artikel ilmiah. Hasil penelitian dari Larasati (2014) dan Gunawan (2018) juga menunjukkan bahwa yang menjadi faktor penghambah penulisan karya ilmiah guru antara lain: 1) karena tidak adanya pendampingan serta terbatasnya referensi maka ide untuk menulis karya ilmia juga tidak berkembang, 2) rendahnya sosialisasi tentang penulisan karya ilmiah yang baik dan benar mengakibatkan terbatasnya wawasan guru tentang penulisan karya ilmiah, 3) waktu yang terbatas karena kecendrungan untuk memenuhi tuntutan administratif dan beban mengajar.

Mengacu pada faktor-faktor permasalahan di atas, maka penyelesaian awal yang harus dilakukan para guru terletak pada diri sendiri. Budaya menulis yang lemah biasanya sejalan 
dengan lemahnya budaya membaca. Oleh karena itu jika ingin memiliki kemampuan menulis yang baik, selain berlatih menulis, seorang guru juga harus memiliki budaya membaca yang tinggi. Minta baca yang rendah menjadi permasalahan utama pada kompetensi pedagogis guru (Wibowo, 2015). Membaca merupakan salah satu langkah untuk memperkaya atau memperbanyak kosa kata yang dimiliki. Selain itu dengan rajin membaca dapat menambah referensi, baik dari penyusunan kalimat, pembendaharaan kata, penyusunan paragraf dan lain sebagainya (Supanti, 2017). Hal ini akan menunjang kemampuan guru dalam menghasilkan karya tulis ilmiah.

Permasalahan yang muncul dari guru terkait artikel ilmiah, terdapat beberapa cara untuk mengatasinya. Salah satu langkah dalam meningkatkan motivasi guru dalam menulis yaitu dengan memperkenalkan berbagai perangkat lunak atau aplikasi penulisan karya ilmiah (Isa, dkk., 2016). Selain itu, pihak sekolah juga dapat melakukan beberapa hal, diantaranya: 1) mengadakan pelatihan penulisan ilmiah profesional, seperti jurnal penelitian, tulisan populer dan lain-lain, 2) mendorong guru untuk mengikuti program hibah penelitian guru, 3) memfasilitasi dan mendorong guru untuk mengikut pertemuan ilmiah terkait penulisan karya tulis ilmiah (Gunawan, 2015); (Prabawati \& Muslim, 2020); (Hodiyanto \& Alimin, 2020) .

\section{SIMPULAN}

Pelaksanaan kegiatan pendampingan dan pelatihan menulis arti penulisan karya ilmiah sangat berguna bagi guru Sekolah Menengah Atas Bahasa Indonesia di Sukoharjo. Pendampingan guru sangat intensif dalam mengikuti pendampingan ini. Berdasarkan pelaksanaan kegiatan pendampingan ini, disimpulkan bahwa; 1) respon peserta dalam menulis artikel atau karya tulis ilmiah adalah cukup tinggi; 2) motivasi menulis artikel ilmiah peserta cukup meningkat; dan 3) meningkatnya keterampilan Guru dalam berliterasi menulis artikel ilmiah. Selain pendampingan ini, terdapat saran bagi guru untuk meningkatkan kemampuan menulis artikel ilmiah di jurnal bagi guru, antaralain mengikuti pertemuan ilmiah guru, seperti diskusi panel, seminar, konferensi, simposium, diskusi akademik, workshop (lokakarya), dan seminar kolegial. Selain itu, pelatihan tulisan profesional seperti penelitian, jurnal, atau tulisan populer di media massa juga perlu dilakukan oleh guru secara periodik waktu tertentu.

\section{PERNYATAAN PENULIS}

Saya dengan ini menyatakan dengan sebenarnya bahwa artikel ilmiah yang berjudul : "Pendampingan Peningkatan Profesionalitas Guru Bahasa Indonesia Melalui Literasi Menulis Artikel di Jurnal Ilmiah”. Menyatakan belum pernah atau tidak akan diterbitkan pada jurnal lain. Apabila dikemudian hari terbukti di publish pada jurnal lain, maka saya bersedia menerima sanksi sesuai ketentutan perundang-undangan yang berlaku

\section{DAFTAR PUSTAKA}

Aisyah, E. N., \& Mahanani, P. (2017). Pelatihan menulisan artikel ilmiah bagi guru sekolah dasar dan taman kanak-kanak kecamatan Tajinan kabupaten Malang. Abdimas Pedagogi: Jurnal Ilmiah Pengabdian kepada Masyarakat, 1(1). 
Firdaus, A. M., Magfirah, N., Syahrir, M., \& Ramdani, R. (2020). IbM Kelompok Guru-Guru SD Inpres Sero di Kecamatan Somba Opu Kabupaten Gowa: Menulis Karya Ilmiah. Jurnal Dedikasi Masyarakat, 3(2), 106-112.

Gunawan, I., Triwiyanto, T., \& Kusumaningrum, D. E. (2018). Pendampingan penulisan artikel ilmiah bagi para guru sekolah menengah pertama. Abdimas Pedagogi: Jurnal Ilmiah Pengabdian kepada Masyarakat, 1(2), 128-135.

Hodiyanto, H., \& Alimin, A. A. (2020). In House Training (IHT) dalam penyusunan karya tulis ilmiah. ABSYARA: Jurnal Pengabdian Pada Masyarakat, 1(2), 56-63.

Ilfiandra, I., Suherman, U., Akhmad, S. N., Budiamin, A., \& Setiawati, S. (2016). Pelatihan dan pendampingan penulisan karya tulis ilmiah bagi guru SD. Jurnal Pengabdian Pada Masyarakat, 1(1), 70-81.

Isa, S. M., Soewito, B., \& Gunawan, F. E. (2016). Pengaruh Perangkat Lunak Managemen Referensi Pada Peningkatkan Motivasi Publikasi Para Pendidik. ETHOS: Jurnal Penelitian dan Pengabdian kepada Masyarakat, 243-248.

Kompas. 2010. Lemah, Kemampuan Guru Menulis Karya Ilmiah, (Online), (http://nasional. kompas.com/read/2010/03/19/04191796/Lemah.Kemampuan.Guru.Menulis.Karya. Ilmiah.), diakses 21 Mei 2021.

Larasati, R. T. (2014). Faktor-faktor Penghambat Penulisan Karya Tulis Ilmiah dalam Pengembangan Keprofesian Berkelanjutan Guru Sekolah Dasar Negeri Lempuyangwangi Yogyakarta. Journal Of Chemical Information And Modeling.

Noorjannah, L. (2014). Pengembangan profesionalisme guru melalui penulisan karya tulis ilmiah bagi guru profesional di SMA Negeri 1 Kauman Kabupaten Tulungagung. Jurnal Humanity, 10(1), 11406.

Prabawati, M. N., \& Muslim, S. R. (2020). Pendampingan Penulisan Artikel Ilmiah Bagi Guru Matematika Sekolah Menengah Pertama Wilayah Sukaraja Kabupaten Tasikmalaya. ABDIMAS: Jurnal Pengabdian Masyarakat, 3(1), 207-212.

Priyanto, I. J., \& Rohartati, S. (2019). Pelatihan Menulis Artikel Ilmiah pada Jurnal Nasional Bagi Guru SDN GBI Bojongsoang, Buahbatu, Kabupaten Bandung. Jurnal Pengabdian Tri Bhakti, 26-29.

Supanti, S. 2017. Solusi Praktis Guru Menulis, (Online), (https://radarsemarang. com/2017/05/21/solusi-praktis-guru-menulis/), diakses 20 Mei 2021.

Wahyuningtyas, N., \& Ratnawati, N. (2018). Pelatihan dan Pendampingan Penulisan Artikel Jurnal bagi Guru-Guru IPS Kabupaten Malang. Jurnal Praksis dan Dedikasi Sosial (JPDS), 40-47.

Wibowo, C. H. (2015). Problematika Profesi Guru dan Solusinya bagi Peningkatan Kualitas Pendidikan di MTs Negeri Nguntoronadi Kabupaten Wonogiri. Media. Neliti. Com. Institut Agama Islam Negeri Surakarta. 